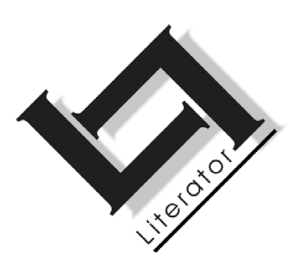

\title{
Affordances of form in stanzaic narrative poetry
}

\author{
B. McHale
}

Department of English

The Ohio State University

$\mathrm{OHIO}$

E-mail: mchale.11@osu.edu

\begin{abstract}
Affordances of form in stanzaic narrative poetry

This article develops the notion that poetry is crucially distinguished from other forms of verbal art by its foregrounding of segmentivity, the spacing of language. If a measure is regarded as the smallest unit of resistance to meaning, measure determines where gaps open up in a poetic text. Poetry is, however, not only measured, but typically countermeasured and narrative in poetry can also be countermeasured against the segmentation that is specific to narrative. The present article investigates segmentivity in one particular type of narrative poem, namely poems in discontinuous stanzaic forms. The concept of affordances (referring to different potentials for use) is applied to the stanzaic form in Edmund Spenser's "The faerie queene" (1590; 1596) and to the "ottava rima" stanza, as exemplified by Kenneth Koch's postmodernist narrative poem, "Seasons on earth" (1960; 1977; 1987).
\end{abstract}




\section{Opsomming}

\section{"Affordances" (Die bevoegdhede) ${ }^{1}$ van vorms in strofiese narratiewe poësie}

In hierdie artikel word die stelling gemaak dat poësie bepalend onderskei kan word van ander vorms van verbale kunswerke op grond van die feit dat segmentering in die poësie voorop gestel word. Indien 'n maatstaf ("measure") beskou word as die kleinste eenheid wat weerstand bied teen betekenisvorming, is dit die mate (as afgemete eenhede) wat bepaal waar daar gapings in poëtiese tekste ontstaan. Poësie is egter nie net afgemete nie, maar daar is ook die moontlikheid van die kontrawerking van ander afgemete stelsels en die narratief in die poësie werk kontrapuntaal in op die segmentering wat eie is aan "tipiese" narratiewe. Hierdie artikel ondersoek segmentering in een spesifieke soort narratiewe gedig, naamlik gedigte met diskontinue strofiese vorms. Die konsep "affordances" (wat verwys na verskillende moontlikhede vir gebruik) word op die strofiese vorm van Edmund Spencer se "The fairie queene" (1590; 1596) toegepas, sowel as op die "ottova rima"-strofiese vorm soos geïllustreer deur Kenneth Koch se postmoderne narratiewe gedig "Seasons on earth" (1960; 1977; 1987).

\section{Introduction}

In this article I pursue some further aspects of a topic I addressed in Beginning to think about narrative in poetry (McHale, 2009). I argued there that poetry is crucially distinguished from other forms of verbal art by its foregrounding of segmentivity - the spacing of language. If this is so, then a priority for narratological approaches to poetry which I advocated in that article - is analysis of the potential for interaction between poetry's segmentation and the segmentation proper to narrative.

I adopt my notion of segmentivity, and the related notions of measure and counter-measure, from Rachel Blau DuPlessis and John Shoptaw, respectively. Poetry, DuPlessis writes, involves "the creation of meaningful sequence by the negotiation of gap (line break,

1 Editor's note: The term "affordances", referring to different potentials for use, does not have an accepted equivalent in Afrikaans or Dutch. In Dutch the term "affordances" are used but there is an internet discussion going on about possible translations. I (H.J.G. du Plooy) would like to propose the term "bevoegdhede" in Afrikaans. The word refers to inherent (but not necessarily realised) potential as well as to being endowed with or allowed to have or display possibilities or functions. 
stanza break, page space)". Poetry "is the kind of writing that is articulated in sequenced, gapped lines and whose meanings are created by occurring in bounded units [...] operating in relation to [...] pause or silence". "These bounded units," DuPlessis goes on, "can be made in varying sizes and with a varying semantic goal":

Line terminations may be rounded off by rhyme, or by specific punctuation marks, but they are basically defined by white space. ... These segmented units can be organized into the larger page-shapes of fixed stanza, or into other pagespace thought units with their termini of various kinds. ... All the meanings poetry makes are constructed by segmented units of a variety of sizes. The specific force of any individual poem occurs in the intricate interplay among the 'scales' (of size or kind of unit) or comes in 'chords' of these multiple possibilities for creating segments. (DuPlessis, 1996:51.)2

Shoptaw (1995:212) defines a poem's measure as "its smallest unit of resistance to meaning". Measure determines where gaps open up in a poetic text, and a gap is always a provocation to meaning-making. It is where meaning-making is interrupted by spacing, where the text breaks off and a gap opens up - even if only an infinitesimal one - that the reader's meaning-making apparatus must gear up to bridge the gap and close the breech. Shoptaw specifies the scales or levels of measure that are possible in poetry. Poetry can be wordmeasured as it is, for instance, in certain modernist one-word-perline poems, e.g. by William Carlos Williams or e.e. cummings; it can be measured at the scale of the phrase as it is, for instance in Emily Dickinson's poetry; it can be measured at the scale of the line as it normally is in most lyric poetry; it can be measured at the level of the sentence as in prose-poetry or in the language poets' practice of the "New sentence" (Shoptaw, 1995:239-251); and it can be measured at the level of the section, as in sonnet cycles or in sequences like The waste land (Shoptaw, 1995:251-255). Moreover, although Shoptaw neglects this possibility, it can also be measured at the level of the stanza, as in the stanzaic narrative forms I propose to begin considering here.

2 In McHale (2009) I asserted that DuPlessis had not reprinted her one-page "Codicil on the definition of poetry" when she reprinted "Manifests", the essay to which it had been attached, in Blue studios (DuPlessis, 2006:73-95). While this is strictly speaking correct, the "Codicil" does in fact appear elsewhere in Blue studios, folded into an essay on George Oppen (DuPlessis, 2006:198-199). 
Poetry is not only measured, but typically countermeasured, so that spacing at one level or scale is played off against spacing at another level or scale: line against sentence, as in enjambed blank verse, phrase against line and stanza, as in Dickinson's poems, et cetera. Narrative poetry, however, can also be countermeasured against the segmentation that is specific to narrative. Narrative is itself segmented at various levels and scales, into events, scenes, plot-moves and episodes at the level of story, into shifting voices and microshifts of focalisation, into segments of time, space and consciousness, and so on. Gaps abound, of all kinds, on all levels. In poetic narratives, narrative's own segmentation interacts with the segmentation "indigenous" to poetry to produce complex interplays among segments of different scales and kinds - "chords" as DuPlessis (1996:51) calls them.

A program of research into narrative in poetry - to which the present article, like its predecessor, aspires to contribute - would focus on these interactions. It might begin by distinguishing provisionally among three broad types of narrative poem, namely poems in continuous forms, such as the classical hexameter, terza rima, the alexandrine, blank verse, and the closed "heroic" couplet; poems in discontinuous stanzaic forms; and modernist and postmodernist narrative poems in free or irregular forms. Of course, even continuousform poetry is segmented, that is, spaced, otherwise it would not function as poetry at all; nevertheless, there are degrees of discontinuity, ranged along a spectrum of possibilities. On that spectrum, narrative stanzaic poems are likely to be more interrupted, "gappier," than poems in blank verse or terza rima.

One part of this research program would explore a family of longer, relatively complex stanza forms featuring interlaced end-rhymes, including ottava rima, rhyme royal, the Spenserian stanza, and the Onegin stanza, and their variants. Each of these forms uses endrhyme to group lines into smaller potential units that might interact in various ways with narrative units - concordantly, where formal units and narrative units coincide, or discordantly, where they diverge, or in various types of counterpoint. Here a useful tool might be the concept of affordances, borrowed from software designers and media theorists, and ultimately from perceptual psychology (cf. Gibson, 1979; Varela et al., 1991). Each of these stanza forms offers different affordances, different potentials for use; each encourages or discourages certain interactions with narrative segments. I am choosing my words carefully: encourage and discourage, rather than constrain or inhibit or determine. Narrative structure is free to over- 
ride the stanzaic structure of narrative poems; it may ignore the promptings or resistances of form. The affordances of form are only options, not mandates.

\section{The Faerie queene stanza (ABABBCBCC)}

Here I want to turn to the first of my two examples: the affordances of Edmund Spenser's stanzaic form in his long narrative poem, The faerie queene $(1590 ; 1596)$. I will be taking advantage of Claire Regan Kinney's excellent analysis of Spenser's narrative poetics (Kinney, 1992). Kinney draws special attention to two of the opportunities for narrative segmentation afforded by the nine-line stanza form that Spenser devised for his poem (see Appendix 1). The interlaced end-rhyme scheme yields two potential quatrain units - $A B A B$ and $B C B C$ - plus a final line that rhymes with lines six and eight; but it also yields what Kinney calls a "displaced couplet" near the middle of the stanza, lines four and five. This displaced couplet throws emphasis on line five, which consequently often functions, Kinney (1992:70) says, as "a pivot about which the stanza doubles back on itself". I am not in a position to say how often in the course of the poem line five's function is pivotal in Kinney's sense, but certainly it is ambiguous in its affiliation, sometimes aligning itself with the first quatrain, to form a five-line unit, sometimes with the second quatrain.

The other affordance of the Spenserian stanza is, of course, its strong closure: the terminal alexandrine decisively ends the unit - so decisively, indeed, that there is essentially no enjambment across stanzas anywhere in The faerie queene. Again, because this is an affordance, not a mandate or prohibition, it would be misleading to claim that it was impossible to construct a narrative segment that straddles adjacent stanzas, but the formal resistance to such overriding of stanza segmentation is so strong that Spenser himself almost never ventures it.

To illustrate the narrative affordances of the Spenserian stanza, I have isolated a sequence of six stanzas from Book 3 , canto 1 (stanzas 14-19; see Appendix 1) that constitute a compact narrative episode comprising several tightly integrated events. This is the first and paradigmatic instance of a plot motif that recurs multiple times throughout Book 3 and its companion, Book 4: a damsel on horseback - in this case Florimell - dashes across the field of vision, with a would-be ravisher in hot pursuit. Major narrative segmentation throughout this miniature six-stanza episode coincides with the intervals between stanzas, reflecting the form's strong closure and resis- 
tance to stanza-to-stanza enjambment. Weaker, less decisive narrative segmentation falls variably around mid-stanza, reflecting the affordances of the "displaced" central couplet.

Events in stanza 14 are recounted in summary: the fairy knight Guyon, Prince Arthur and his squire Timias, and the female knight Britomart travel Long and At length through a wilderness landscape. The change of narrative pace to scene is signaled at the beginning of stanza 15: All suddenly Florimell streaks across the knights' field of vision. The likelihood that this stanza reflects their collective focalisation of her is confirmed by the last phrase, her passing to behold. (There is also a trace of embedded focalisation: they see that she is seeing something - her eye she backward threw, stanza 16 - though what she is seeing does not actually appear until stanza 17.) The substance of the knights' vision in stanza 15 is, in effect, a partial blason of Florimell, presumably foreshortened by the speed of her passage: they first register her horse (milk-white), then her face; then her garments and her horse's trappings. Here line five has been absorbed into the first unit (horse and damsel); the shift to garments and trappings occurs from line six (with its $C$ rhyme).

The mid-stanza shift in stanza 16 occurs a line earlier than in stanza 15: the first quatrain unit continues the blason (her hair); the second quatrain shifts to an epic simile at the discourse level (All as a blazing starre and so on): her passage (and especially her hair streaming out behind her) is like a comet. I identify this as a shift to the discourse level on the assumption that this simile is attributable directly to the poet, who does not belong to the poem's storyworld, but it might just as plausibly be construed as reflecting what is passing through the knights' minds, and in that sense to belong to the level of the storyworld.

At the beginning of stanza 17, the object of the knights' focalisation changes. Florimell has passed out of sight, and in her place they see her pursuer: So as they gazed after her a while, / Lo where a griesly Foster forth did rush. Here the mid-stanza shift that the form affords is overridden, and the description of the Forester's abuse of his mount extends from line three to seven, without regard to the groupings proposed by the rhyme scheme. The knights' focalisation of the Forester is reiterated at the beginning of stanza 18 - when those gentle knights did see - and now they spring into action, riding off to rescue Florimell.

Or more exactly, they all ride off except for Britomart, the Knight of Chastity, who, refusing to be swept up in the passions of the mo- 
ment, keeps her wits about her and stays put. Stanza 19 shifts to her individual point of view, and we get a glimpse of what is passing through her mind. At this point, the plot of Book 3 splits into several strands, and the interlacement of plot-strands that Spenser learned from Ariosto and medieval romance begins. We continue to follow Britomart through the rest of this canto and most of the next three, only resuming Prince Arthur's thread three-quarters of the way through canto 4, and Timias's part-way into canto 5. (Unless I am mistaken, Guyon disappears from this book altogether.)

In this example, the formal segmentation afforded by the rhymescheme and the strong closure of the stanza's final alexandrine generally coincide with narrative segmentation. Apart from one instance (stanza 17) where narrative continuity overrides the segmentation afforded by the form, the relation between stanza form and narrative here is generally concordant, which is typical of Spenser's poetics throughout The faerie queene.

\section{Ottava rima (ABABABCC)}

For my second example, I am relying on Catherine Addison's (2004) brilliant account of what she does not quite call - though she might have - the narrative affordances of the ottava rima stanza. Organised by its end-rhymes into an interlaced sestet (ABABAB) and a separate couplet (CC), the ottava rima stanza, Addison argues, is predisposed by its verse design - its affordances - to accommodate novelistic discourse. The alternating rhymes of the sestet means that these lines tend to "lean forward" (Addison, 2004:133), encouraging narrative progress, while the couplet breaks sharply from the sestet, accommodating a shift into reflection, commentary, irony, aphorism, or a different voice or perspective. In other words, ottava rima is something like a template for the polyvocality that Mikhail Bakhtin (1981) associated with the novel. Surely it is no accident that Bakhtin's paradigmatic case of novelistic discourse is Pushkin's Evgeny Onegin, a verse-novel using a stanzaic form that is a near cousin of ottava rima.

According to Addison (2004:134), the Italian Renaissance poets Ariosto and Tasso used ottava rima to produce "not epics but novels" - Ariosto gleefully, Tasso somewhat reluctantly. Ariosto exploited the couplet to shift from narrative to commentary, especially ironic commentary, juxtaposing incongruent viewpoints. Tasso, more invested in unity and epic decorum, resisted this kind of irony, but the ottava rima form sometimes betrayed him into it anyway. Lord Byron, of course, took full advantage of the ottava rima stanza's 
capacity for polyvocalism in Don Juan. Typical of what Addison (2004:139) calls his "shock tactics" is Bryon's use of the couplet to produce an abrupt shift in tone from serious to facetious, or vice versa, or a shift from story to discourse or from discourse to story, or from one focaliser to another.

Instead of illustrating these Byronic shock tactics with an example from Don Juan itself, however, let me use one from a later practitioner of the ottava rima in Lord Byron's mode: Kenneth Koch in The duplications (1977), the second installment of a long narrative poem eventually published under the title, Seasons on earth (Koch, 1987; the first installment in 1960 was Ko, or $A$ season on earth). Addison (2004:140) singles out one particular stanza of The duplications to illustrate Koch's Byronic use of the affordances of the ottava rima form; this is the third of the stanzas reproduced in Appendix 2. The inhabitants of the island of Samos have been swept into the sea by a catastrophic tidal wave, and the sestet of this stanza voices their collective reflections on their situation, using free indirect style:

To stay afloat and find their island home Just one more time, and then, they vowed, forever

They'd be obedient to the speechless dome

And parchless eye of heaven; they would never

Do any bad or selfish thing, nor roam

From Samos off to any place whatever.

The couplet shifts abruptly into a different voice, reframing the Samians' plight in an ironic perspective (Koch, 1977:39):

These vows were heard by no one but the fishes

Whom usually they fried and served on dishes

Addison is quite right, of course, to single this stanza out as an example of concord between poetic segmentation (the shift from sestet to couplet), and narrative segmentation (the shift between the Samians' voice and perspective and those of the ironising narrator). However, in isolating this stanza from its immediate context, she obscures the ways that Koch overrides formal segmentation at one level of organisation even as he avails himself of its affordances at another.

For the two narrative segments that make up this stanza - let's say, roughly, a story-level segment (events, including verbal events) in the sestet, and a discourse-level segment (commentary) in the couplet - are both in fact continuous with the adjacent stanzas, 
before and after; they are both enjambed segments. The preceding stanza is comprised, except for its last line, of aphorisms attributable to the narrator, reflecting in gnomic present tense on life in general: Life's simple in such crisis situations and so on. Only in the last line of that stanza do we return to the storyworld of the Samians, and to the "epic preterite" of narration - As these folks did at sea while struggling in it - a sentence whose continuation is found on the other side of the white space in the next stanza: To stay afloat and find their island home. Similarly, the ironic reframing that occurs in the couplet of this stanza actually spills over into the following one (as the absence of punctuation at the end of the stanza's last line signals): Whom usually they fried and served on dishes / With lemon on the side, and sometimes rice.

Thus, in this passage Koch exploits the narrative affordances of ottava rima form in some respects - in his use of the couplet to introduce polyvocality - but ignores them in his overriding of the stanza breaks. This willingness to exploit dissonance between stanzaic form and narrative segmentation is as typical of Koch's poetics as consonance is of Spenser's. We could begin to historicise Koch's practice by saying that, if Koch learned the "shock tactics" of his couplet from Lord Byron, he could not have learned his overriding of the stanza break from him, because Byron almost never enjambs stanzas in Don Juan. Instead, the likeliest model for Koch's enjambment of stanzas is Pushkin's Onegin, because Pushkin overrides stanza breaks quite freely, as he does other units of poetic segmentation. But analysis of the affordances of the Onegin stanza and the complexities of Pushkin's practice will have to wait for another occasion. ${ }^{3}$

\section{Appendix 1}

\section{Edmund Spenser, The faerie queene (1590) III.1.14-19}

14

Long they thus trauelled in friendly wise,

Through countries waste, and eke well edifyde,

Seeking aduentures hard, to exercise

Their puissance, whylome full dernely tryde:

At length they came into a forrest wyde,

3 A starting point might be Scherr (2006). I am grateful to my colleague Eyal Segal for calling my attention to this article. 
Whose hideous horror and sad trembling sound

Full griesly seem'd: therein they long did ryde,

Yet tract of liuing creatures none they found,

Saue Beares, Lions, \& Buls, which romed them around.

\section{5}

All suddenly out of the thickest brush, Upon a milk-white Palfrey all alone, A goodly Ladie did foreby them rush, Whose face did seeme as cleare as Christall stone, And eke through feare as white as whales bone: Her garments all were wrought of beaten gold, And all her steed with tinsell trappings shone, Which fled so fast, that nothing mote him hold, And scarse them leasure gaue, her passing to behold.

\section{6}

Still as she fled, her eye she backward threw, As fearing euill, that pursewd her fast; And her faire yellow locks behind her flew, Loosely disperst with puffe of euery blast: All as a blazing starre doth farre outcast His hearie beames, and flaming lockes dispred, At sight whereof the people stand aghast: But the sage wisard telles, as he has red, That it importunes death and dolefull drerihed.

\section{7}

So as they gazed after her a while, Lo where a griesly Foster forth did rush, Breathing out beastly lust her to defile: His tyreling iade he fiercely forth did push, Through thicke and thin, both ouer banke and bush In hope her to attaine by hooke or crooke, That from his gorie sides the bloud did gush: Large were his limbes, and terrible his looke, And in his clownish hand a sharp bore speare he shooke.

18

Which outrage when those gentle knights did see,

Full of great enuie and fell gealosy,

They stayd not to auise, who first should bee,

But all spurd after fast, as they mote fly,

To reskew her from shamefull villany.

The Prince and Guyon equally byliue

Her selfe pursewd, in hope to win thereby

Most goodly meede, the fairest Dame aliue:

But after the foule foster Timias did striue. 
19

The whiles faire Britomart, whose constant mind, Would not so lightly follow beauties chace, Ne reckt of Ladies Loue, did stay behind, And them awayted there a certaine space, To weet if they would turne backe to that place: But when she saw them gone, she forward went, As lay her iourney, through that perlous Pace, With stedfast courage and stout hardiment; $\mathrm{Ne}$ euill thing she fear'd, ne euill thing she ment.

\section{Appendix 2}

\section{Kenneth Koch, The duplications (Koch, 1977:38-39)}

Yes, there was nothing on this island now:

No eagles, no bazoukis, no percussion, No moussaka, no blossoms on the bough Of the delightful peartree where the buzzing Of bees made glad the lad who led the cow; And all the persons who had been discussing The ways to solve their personal problems are Gasping at sea and cling to any spar.

Life's simple in such crisis situations,

Provided they don't last for very long:

Such fortitude, such sympathy, such patience, Such pleasure in a patriotic song!

Too bad that just by decimating nations

One usually has such things. It's wrong. One ought to live as nobly every minute As these folks did at sea while struggling in it

To stay afloat and find their island home Just one more time, and then, they vowed, forever They'd be obedient to the speechless dome And parchless eye of heaven; they would never Do any bad or selfish thing, nor roam From Samos off to any place whatever. These vows were heard by no one but the fishes Whom usually they fried and served on dishes

With lemon on the side, and sometimes rice. These edibles, though, found incomprehensible Their human language, which did not suffice To make the fish do anything more sensible Than swimming out of earshot. Fish are nice 
In being, though we eat them, not revengeful.

I think that we would probably be meaner

To those who washed us down with their retsina!

However, back to Huddel ...

\section{List of references}

ADDISON, C. 2004. Ottava rima and novelistic discourse. Journal of narrative theory, 34(2):133-145.

BAKHTIN, M.M. 1981. The dialogic imagination: four essays. Ed. and trans. by C. Emerson \& M. Holquist. Austin: University of Texas Press.

DUPLESSIS, R.B. 1996. Manifests. Diacritics, 26(3 \& 4):31-53.

DUPLESSIS, R.B. 2006. Blue studios: poetry and its cultural work. Tuscaloosa: University of Alabama Press.

GIBSON, J.J. 1979. A theory of affordances. (In Gibson, J.J. An ecological approach to visual perception. Boston: Houghton-Mifflin. p. 127-143.)

KINNEY, C.R. 1992. Strategies of poetic narrative: Chaucer, Spenser, Milton, Eliot. Cambridge: Cambridge University Press.

$\mathrm{KOCH}, \mathrm{K} .1977$. The duplications. New York: Random House.

McHALE, B. 2009. Beginning to think about narrative in poetry. Narrative, 17(1): 11-30.

SCHERR, B. 2006. Structural dynamics in the Onegin stanza. (In Dresher, B.E. \& Friedberg, N., ed. Formal approaches to poetry: recent developments in metrics. Berlin: De Gruyter. p. 267-286.)

SHOPTAW, J. 1995. The music of construction: measure and polyphony in Ashbery and Bernstein. (In Schultz, S., ed. The tribe of John: Ashbery and contemporary poetry. Tuscaloosa: University of Alabama Press. p. 211257.)

SPENSER, E. 1590. The faerie queene, book 3. http://www.luminarium. org/renascence-editions/queene3.html\#Canto\%20I Date of access: 7 Mar. 2011.

VARELA, F.J., THOMPSON, E. \& ROSCH, E. 1991. The embodied mind: cognitive science and human experience. Cambridge: MIT.

Key concepts:

affordance

narrative poetry

ottava rima

segmentivity

Spenserian stanza

stanzaic poetry
Kernbegrippe:

"affordances"

narratiewe poësie

ottava rima

segmentering

Spenserse strofes

strofiese versvorm 